\title{
GAIN VELOCITY AND IGA SECRETORY FECAL BETWEEN PRETERM BABY RECEIVED HUMAN MILK AND HUMAN MILK FORTIFIED
}

\author{
Kartika Darma Handayani1 $^{*}$, Risa Etika ${ }^{1}$, Nurita Alami Dwi Wijayanti ${ }^{1}$, Agus Harianto ${ }^{1}$, \\ Martono Tri Utomo ${ }^{1}$, Dina Angelika ${ }^{1}$, Mahendra Tri Arif Sampurna ${ }^{1}$ \\ ${ }^{I}$ Depatment of Pediatrics, Faculty of Medicine, Universitas Airlangga, Dr. Soetomo General Hospital, \\ Surabaya, Indonesia \\ *kartika09rama@gmail.com \\ https://doi.org/10.34302/crpjfst/2019.11.5.16

\begin{tabular}{|c|c|}
\hline Article history: & ABSTRACT \\
\hline $\begin{array}{l}\text { Received: } \\
9 \text { March } 2019\end{array}$ & $\begin{array}{l}\text { Preterm baby suffered from metabolic stress and hypogammaglobulinemia } \\
\text { after birth. Extrauterine growth restriction (EUGR) is a common problem }\end{array}$ \\
\hline Accepted: & and related to neurodevelopmental outcome. The Independent risk factor of \\
\hline 20 September 2019 & EUGR is necrotizing enterocolitis (NEC). Concentration secretory IgA \\
\hline $\begin{array}{l}\text { Keywords: } \\
\text { Preterm baby: }\end{array}$ & $\begin{array}{l}\text { (sIgA) as main immunity system decreased by age. Human milk fortification } \\
\text { may resolve EUGR and organ immaturity of preterm baby. }\end{array}$ \\
\hline Human milk; & Objective : Analyzed difference gain velocity and sIgA fecal between \\
\hline Fortification; & preterm baby received human milk and human milk fortified. \\
\hline Gain velocity; & Methods : Prospective analytic observational study between December \\
\hline sIgA fecal. & $\begin{array}{l}\text { 2015-July } 2016 \text { at Soetomo Hospital Surabaya. Inclusion criteria consisted } \\
\text { of gestational age }<34 \text { weeks and birth weight } 1000 \text { till less than } 2000 \text { g }\end{array}$ \\
\hline & Multiple congenital anomaly and enteral nutrition avoidance as exclusion \\
\hline & $\begin{array}{l}\text { criteria. Indication human milk fortification were stable period, no suckling } \\
\text { reflex and gain weight velocity }(\mathrm{GWV})<10 \mathrm{~g} / \mathrm{kg} / \mathrm{d} \text {. Preterm baby was }\end{array}$ \\
\hline & $\begin{array}{l}\text { recruited and followed in } 14 \text { days. Chi-square, Mann-whitney and t-test } \\
\text { independent sample used to analyzed discrepancies GWV, gain length }\end{array}$ \\
\hline & velocity (GLV), gain head circumference velocity (GHC) and sIgA fecal. \\
\hline & Results : Human milk fortification $(22(12,86-51,76) \mathrm{g} / \mathrm{kg} /$ day $)$ showed \\
\hline & $\mathrm{g} / \mathrm{kg} / \mathrm{day})$ group $(\mathrm{p}=0,020) . \operatorname{GLV}(\mathrm{p}=0,257), \operatorname{GHC}(\mathrm{p}=0,215)$ and $\operatorname{sIgA}$ fecal \\
\hline & $(\mathrm{p}=0,418)$ revealed no difference. Side effects (feeding intolerance and \\
\hline & $\begin{array}{l}\text { NEC) not found during observation. } \\
\text { Conclusions : Human milk fortification showed higher GWV than human }\end{array}$ \\
\hline & \\
\hline
\end{tabular}

\section{Introduction}

Prematurity infants have growth problems at 36 weeks postmenstrual age $(91 \%)$ and mature (30\%) (Fanaroff et al., 2007; Leppänen et al., 2014). Growth disorders cause neurodevelopmental disorders, cognitive function, and quality of life of prematurity infants, one of the disturbances in gastrointestinal organs (Cooke et al., 2003). In prematurity infants, there is Immunoglobulin A (the main body's immune system in the gastrointestinal tract) and breast milk is the main source of IgA but its levels decline with the age of prematurity infants (Araújo and Gonçalves, 2005). Growth rates of weight gain were lower in 171 underweight infants who received breast milk $>75 \%$ (Colaizy, 2012). Therefore, it needs optimal nutritional support in prematurity infants to fit the intrauterine growth rate based on postconceptional age guidelines (American Academy of Nutrition Committee on Nutrition, 1977). 
The technique of giving fortification to proper infant breastmilk is still continuously studied, as it found in the Gross study that the standard fortification for infants less than 24 $\mathrm{kcal} / \mathrm{oz}$ was not able to meet the growth rate (Gross, 1987). Meanwhile, standard fortification according to Schutzman of $22 \mathrm{kcal} / \mathrm{oz}$ is recommended in prematurity infants with a birth weight of 1000-2000 grams. In 2 cases of underweight infants at Dr. Soetomo General Hospital Surabaya with fortification standard 22 kcal / oz (gestational age 31-33 weeks and birth weight 1400-1500 gram) showed that short-term growth rate (body weight $21.21 \mathrm{~g} / \mathrm{kg} /$ day, 1 $\mathrm{cm} /$ week body length and head circumference $1.75 \mathrm{~cm} /$ week) whereas in 4 underweight babies with standard fortification $24 \mathrm{kcal} / \mathrm{oz}$ often showed sepsis with feeding intolerance. Adjustable fortification is an invasive technique that shows the growth rate of body length is not significantly different, and the constraint of its implementation is the availability of protein supplementation. (Arslanoglu et al., 2006). Tailored fortification is believed to be an appropriate fortification technique but it is expensive and the procedure is complicated (Reali et al., 2010).

Accordance with the Republic of Indonesia Government Regulation No. 33 the Year 2012 on exclusive breastfeeding and Regulation of the Republic of Indonesia Health Minister No.39 Year 2013 on infant formula and other infant products, strict evaluation and monitoring of infant formula usage, both from government and related institutions. In this study, observation and analysis of short-term growth rate and immune system of underweight infants receiving breast milk and breast milk were fortified with HMF by anthropometric method and examination of secretory $\operatorname{IgA}, \operatorname{IgE}$ levels. This study aims to find a proper milking fortification technique and safe to overcome extrauterine growth restriction events and reduce the incidence of infection in infants less months. Thus, researchers observed and analyzed prematurity infants as indicated by breastfeeding fortification with HMF.

\section{Materials and methods}

This design of this study is a prospective analytic observational design. The study was conducted in the nursery Dr. Soetomo General Hospital Surabaya, which it begins December 2015 - July 2016. Samples were taken by consecutive sampling with a sample of 17 babies. The population of the samples was breastfed infants and breastmilk fortified with HMF (ASI + HMF) with inclusion criteria: Pregnancy age $\leq 34$ weeks of gestational, birth weight 1000-2000 grams, subjects whose parents had signed an informed consent at the start of the study.

\section{Results and discussions}

The collection of research subjects was conducted from December 2015 to July 2016 and obtained 17 infants underwent indication of breastfeeding fortification (gestational age $\leq 34$ weeks, birth weight 1000-2000 grams) and with the approval of the Neonatology Division staff Dr. Soetomo General Hospital Surabaya. Other considerations include poor feeding ability, no history of feeding intolerance, not being treated with oxygen supplementation, not in sepsis. Infants less than matched according to the above criteria will receive HMF fortified milk for 14 days and evaluated anthropometric and secretory IgA parameters before and after the study and monitored adverse effects of feeding intolerance and necrotizing enterocolitis (NEC).

The characteristics of mothers at the research subjects showed no significant differences in age, nutritional status, history of parity, history of preeclampsia / eclampsia, risk of delivery and history of specific illness during pregnancy in Table $1(\mathrm{p}>0.05)$. Characteristics in socio-economic status of both groups showed no significant difference $(p>0.05)$ in the education of the father and mother, father's work and mother, income and status home ownership in Table 2. Characteristics of study subjects in terms of sex, type of labor, Apgar score $1 \mathrm{~min}$, Apgar score 5 min gestational age, birth weight (z-score), z-score, premature rupture of membranes, amniotic fluid, history of corticosteroid administration before delivery, 
neonatal jaundice, seizures, sepsis, oxygen source and type of breastmilk did not get significant difference $(\mathrm{p}>0.05)$ in Table 3 . Characteristics of the subjects before breastfeeding fortification did not show significant differences $(\mathrm{p}>0.05)$ between breastfed and breast-fed groups were fortified with HMF in terms of body weight, z-score, body length $(\mathrm{cm}), \mathrm{z}$-score, head circumference $(\mathrm{cm}), \mathrm{z}$-score head, fecal concentration of secretory IgA, chronological age, average enteral volume ( $\mathrm{ml} /$ day) and $(\mathrm{ml} / \mathrm{kg} /$ day) in Table 4 .

Table 1. Characteristics of research subject mothers

\begin{tabular}{|l|c|c|c|}
\hline \multicolumn{1}{|c|}{ Characteristics } & Breastfed & $\begin{array}{c}\text { Breastfed } \\
\text { Fortification } \\
\text { HMF } \\
\text { (n=17) }\end{array}$ & p \\
\hline Age (years) & $28,82 \pm 5,90$ & $28,82 \pm 5,71$ & $1,000^{3}$ \\
\hline $\begin{array}{l}\text { Nutritional Status (kg/m } \mathbf{2}) \\
\text { Malnutrition }\end{array}$ & 2 & 2 & $0,714^{2}$ \\
$\begin{array}{l}\text { Normal } \\
\text { Overweight }\end{array}$ & 13 & 14 & \\
\hline $\begin{array}{l}\text { History of parity } \\
\text { Gravida 1 }\end{array}$ & 2 & 1 & $0,571^{2}$ \\
$\begin{array}{l}\text { Gravida 2 } \\
\text { Gravida 3 } \\
>\text { Gravida 3 }\end{array}$ & 5 & 7 & \\
\hline $\begin{array}{l}\text { pre-eclampsia/eclampsia } \\
\text { history }\end{array}$ & 1 & 6 & $1,000^{1}$ \\
\hline Risk of Labor & 6 & 0 & $0,721^{1}$ \\
$\begin{array}{l}\text { High } \\
\text { Low }\end{array}$ & 10 & 5 & $1,000^{1}$ \\
\hline $\begin{array}{l}\text { history of specific illness } \\
\text { during pregnancy }\end{array}$ & 1 & 12 & 6 \\
\hline
\end{tabular}

Description: The value of $p$ is significant when the value $<0,05$. Chi-square test ${ }^{1}$, Mann-Whitney ${ }^{2}$ test and independent sample ${ }^{3}$ test

Table 2. Characteristics of socioeconomic status of parents

\begin{tabular}{|l|c|c|c|}
\hline \multicolumn{1}{|c|}{ Characteristic } & Breastfed & $\begin{array}{c}\text { Breastfed } \\
\text { Fortification } \\
\text { HMF } \\
(\mathbf{n = 1 7 )}\end{array}$ & p \\
\hline Father's education & 0 & 1 & $0,736^{2}$ \\
Didn't School & 1 & 0 & \\
Elementary School & 3 & 3 & \\
Junior High School & 10 & 10 & \\
Senior High School & 3 & 3 & $0,740^{2}$ \\
Bachelor (S1/S2/S3) & 3 & 1 & \\
Mother's Education & 2 & 3 & \\
Elementary School & 3 & & \\
Junior High School & &
\end{tabular}




\begin{tabular}{|c|c|c|c|}
\hline $\begin{array}{l}\text { Senior High School } \\
\text { Bachelor (S1/S2/S3) }\end{array}$ & $\begin{array}{l}9 \\
3 \\
\end{array}$ & $\begin{array}{c}10 \\
3\end{array}$ & \\
\hline $\begin{array}{l}\text { Father's Job } \\
\text { Working } \\
\text { Not Working }\end{array}$ & $\begin{array}{c}17 \\
0\end{array}$ & $\begin{array}{c}16 \\
1\end{array}$ & $1,000^{1}$ \\
\hline $\begin{array}{l}\text { Mother's Job } \\
\text { Working } \\
\text { Not Working } \\
\end{array}$ & $\begin{array}{c}4 \\
13 \\
\end{array}$ & $\begin{array}{l}13 \\
12 \\
\end{array}$ & $1,000^{1}$ \\
\hline $\begin{array}{l}\text { Income } \\
\text { Insufficient } \\
\text { Sufficient } \\
\text { More than enough }\end{array}$ & $\begin{array}{c}10 \\
7\end{array}$ & $\begin{array}{c}7 \\
10\end{array}$ & $0,494^{2}$ \\
\hline $\begin{array}{l}\text { Home Ownership } \\
\text { Status } \\
\text { One's Own } \\
\text { Family Owner } \\
\text { Someone else }\end{array}$ & $\begin{array}{l}5 \\
9 \\
3\end{array}$ & $\begin{array}{l}5 \\
9 \\
3\end{array}$ & $1,000^{2}$ \\
\hline
\end{tabular}

Description: The value of $\mathrm{p}$ is significant when the value $<0,05$. Chi-square ${ }^{1}$ Test and Mann-Whitney ${ }^{2}$ Test

Table 3. Characteristic of Research Subject

\begin{tabular}{|c|c|c|c|}
\hline Characteristic & $\begin{array}{c}\text { Breastfed } \\
(n=17)\end{array}$ & $\begin{array}{c}\text { Breastfed } \\
\text { Fortification HMF } \\
(\mathbf{n}=17)\end{array}$ & $\mathbf{p}$ \\
\hline $\begin{array}{l}\text { Sex (n) } \\
\text { Male } \\
\text { Female }\end{array}$ & $\begin{array}{l}8 \\
9\end{array}$ & $\begin{array}{l}8 \\
9\end{array}$ & $1,000^{1}$ \\
\hline $\begin{array}{l}\text { Type of Parity } \\
\text { Normal } \\
\text { Cesarean section } \\
\end{array}$ & $\begin{array}{c}7 \\
10\end{array}$ & $\begin{array}{c}7 \\
10\end{array}$ & $1,000^{2}$ \\
\hline Apgar score 1 minute & $6(1-8)$ & $6(1-8)$ & $0,722^{2}$ \\
\hline Apgar score 5 minute & $8(3-9)$ & $8(3-9)$ & $0,750^{2}$ \\
\hline Gestational Age (week) & $32(30-34)$ & $31(30-34)$ & $0,110^{2}$ \\
\hline Aterm & 17 & 17 & - \\
\hline $\begin{array}{l}\text { Birth Weight (g) } \\
\text { Birth Weight to Age (z-score) }\end{array}$ & $\begin{array}{c}1700(1000-1900) \\
-0,73 \pm 0,82 \\
\end{array}$ & $\begin{array}{c}1650(1000-1950) \\
-0,26 \pm 0,80\end{array}$ & $\begin{array}{l}0,986^{2} \\
0,101^{3} \\
\end{array}$ \\
\hline $\begin{array}{l}\text { Birth Length (cm) } \\
\text { Birth Length (z-score) }\end{array}$ & $\begin{array}{l}41,58 \pm 2,92 \\
-0,72 \pm 1,25\end{array}$ & $\begin{array}{l}41,58 \pm 3,04 \\
-0,32 \pm 1,07\end{array}$ & $\begin{array}{l}1,000^{3} \\
0,329^{3}\end{array}$ \\
\hline $\begin{array}{l}\text { Birth Head } \\
\text { Circumference(cm) } \\
\text { Birth Head Circumference (z- } \\
\text { score) }\end{array}$ & $\begin{array}{c}29(25-32) \\
-0,36(-2.02-(+0,59))\end{array}$ & $\begin{array}{c}29(22-31) \\
-0,59(-1,90-(+1,25))\end{array}$ & $\begin{array}{l}0,169^{2} \\
0,581^{2}\end{array}$ \\
\hline $\begin{array}{l}\text { Prematurity of Rupture } \\
\text { Membrane }\end{array}$ & 4 & 10 & $0,080^{1}$ \\
\hline $\begin{array}{l}\text { Amniotic fluid } \\
\text { Clear } \\
\text { Murky }\end{array}$ & $\begin{array}{c}16 \\
1\end{array}$ & $\begin{array}{c}15 \\
2\end{array}$ & $1,000^{1}$ \\
\hline
\end{tabular}




\begin{tabular}{|l|c|c|c|}
\hline $\begin{array}{l}\text { History of antenatal } \\
\text { corticosteroid administration }\end{array}$ & 6 & 9 & $0,491^{1}$ \\
\hline Icterus Neonatal & 16 & 16 & $1,000^{1}$ \\
\hline Seizure & 0 & 1 & $1,000^{1}$ \\
\hline Sepsis & 6 & 6 & $1,000^{1}$ \\
\hline Oxygen & 2 & 0 & $0,220^{1}$ \\
Room & 15 & 15 & \\
CPAP & 0 & 1 & \\
Ventilator & 3 & 2 & $0,949^{2}$ \\
\hline Type of breastfed & 11 & 13 & \\
Week 1 & 3 & 2 & \\
Week 2 & 3 & & \\
Week 3/4 & & & \\
\hline
\end{tabular}

Description: $\mathrm{P}$ value means when value $<0,05$. Chi-square ${ }^{1}$ test, Mann-whitney ${ }^{2}$ test and t-test independent sample 3

Table 4. Characteristic of Subject before Breastfeeding Fortification

\begin{tabular}{|l|c|c|c|}
\hline \multicolumn{1}{|c|}{ Characteristic } & Breastfed $(\mathbf{n = 1 7 )}$ & $\begin{array}{c}\text { Breastfed } \\
\text { Fortification HMF } \\
(\mathbf{n}=\mathbf{1 7})\end{array}$ & $\mathbf{p}$ \\
\hline Weight (g) & $1590(1070-1950)$ & $1620(1160-1770)$ & $0,629^{1}$ \\
\hline Weight to Age (z-score) & $-1,52 \pm 0,65$ & $-1,32 \pm 0,56$ & $0,379^{2}$ \\
\hline Length (cm) & $42,53 \pm 2,70$ & $43,09 \pm 2,50$ & $0,322^{2}$ \\
\hline Length to Age (z-score) & $-1,20 \pm 1,29$ & $-0,51 \pm 1,02$ & $0,930^{2}$ \\
\hline Head Circumference (cm) & $29,26 \pm 2,05$ & $29,32 \pm 1,86$ & $0,931^{2}$ \\
\hline $\begin{array}{l}\text { Head Circumference to } \\
\text { Age (z-score) }\end{array}$ & $-1,17 \pm 0,87$ & $-0,86 \pm 1,12$ & $0,381^{2}$ \\
\hline IgA secretory fecal ( $\boldsymbol{\mu g} / \mathbf{m l})$ & $1312,90(194,43-$ & $1299,65(63,18-$ & $0,082^{1}$ \\
\hline Age of Chronology (day) & $2304,60)$ & $1373,62)$ & \\
\hline Enteral Volume (ml/day) & $11,41 \pm 3,43$ & $11,41 \pm 3,54$ & $1,000^{2}$ \\
\hline $\begin{array}{l}\text { Enteral Volume } \\
\text { (ml/kg/day) }\end{array}$ & $192(180-300)$ & $216(180-300)$ & $0,133^{1}$ \\
\hline
\end{tabular}

Description: The value of $p$ is significant when the value $<0,05$.Mann-Whitney ${ }^{1}$ test and independent $t-$ test sample ${ }^{2}$

Weight (gram) and age-weighted (z-score) parameters showed significantly different changes $(p<0.05)$ and in the breastmilk group $192.65 \pm 170.78$ grams and the breastfeeding group was fortified with HMF 355. 88 \pm 162.30 grams. In the parameter of body length $(\mathrm{cm})$, head circumference $(\mathrm{cm})$ and the secretory $\operatorname{IgA}$ did not show significantly different changes $(p>0.05)$ in Table 5 . The breastfed group of fortified HMF had a faster growth rate of body weight of $22(12.86-51.76) \mathrm{g} / \mathrm{kg} /$ day than the breastfeeding group $14.28(-12.86-(+32.86) \mathrm{g}$ $/ \mathrm{kg} /$ day $(\mathrm{p}=0,020)$. While growth rate of body length and head circumference did not show significant difference $(p>0.05)$ presented in Table 6 . The mean age-to-weight (z-score) score was higher in the HMF-fortified breastfeeding group than in the breast milk group. Mean ageweighted values did not show significant differences at birth, before fortification and day 7 ( $>0.05)$. However, the mean value of body 
weight according to age at day 14 showed significant difference $(\mathrm{p}<0.05)$ in Figure 1.

The mean length-for-age (z-score) rate was higher in the HMF-fortified breastfeeding group than in the breastmilk group. The mean value of body length according to age did not show significant difference at birth $(\mathrm{p}>0.05)$, before fortification and day 7 . The mean value of body length according to age at day 14 showed a significant difference $(\mathrm{p}<0.05)$ in Figure 2. The mean age of $\mathrm{z}$-score head circumference was higher in the breastfed fortified HMF group than in the breastmilk group. The mean head circumference value according to age did not show significant difference at birth $(p>0.05)$, before fortification, day 7 and day 14 in Figure 3.
The mean of enteral volume in breastmilk group was $178,42 \pm 17,85 \mathrm{ml} / \mathrm{kg} /$ day and breastfed group was fortified HMF $175,04 \pm 13,91 \mathrm{ml} / \mathrm{kg} /$ day were given in Table 7 indicating no significant difference. While caloric mean showed significant difference that was in breastfed group of HMF $144,47 \pm 10,03$ $\mathrm{kkal} / \mathrm{kg} /$ day and milk group 119,17 $\pm 14,17$ $\mathrm{kcal} / \mathrm{kg} /$ day $(\mathrm{p}<0.05)$ in Table 8. The mean protein values were significantly different in the breastfed group of HMF $5.44 \pm 0.49 \mathrm{~g} / \mathrm{kg}$ / day

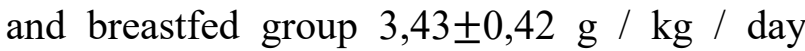
$(p<0.05)$ presented in Table 9. During the study, side effects of feeding intolerance with systemic symptoms and NEC were not found.

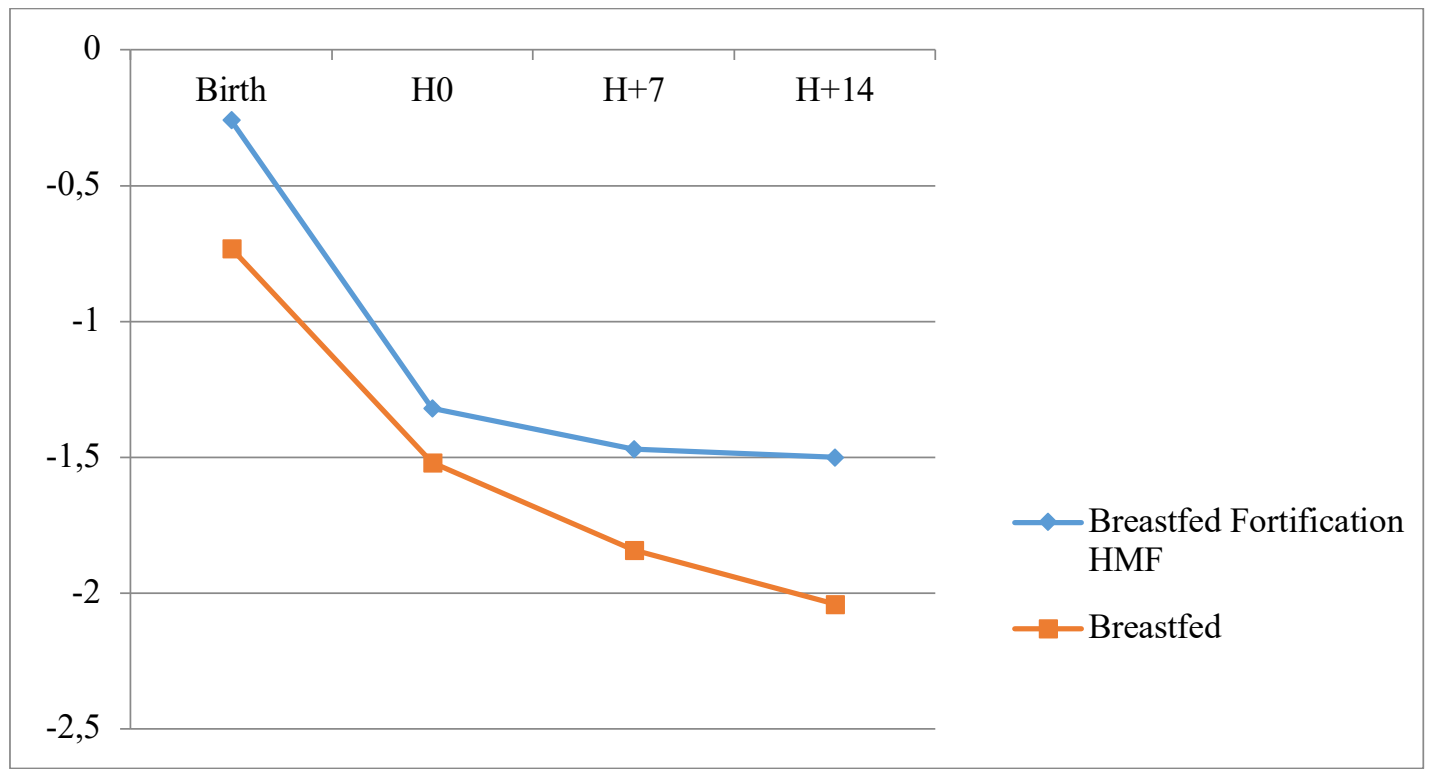

Figure 1. Comparison of mean age-weight (z-score) between breastfeeding and breast milk group was fortified by HMF. Description: blue line is a group of breastfed fortified HMF and red line is a breastmilk group. The $\mathrm{p}$ value is significant when the value is $<0,05$. Mann-Whitney ${ }^{1}$ test and independent $\mathrm{t}$-test sample ${ }^{2}$. 


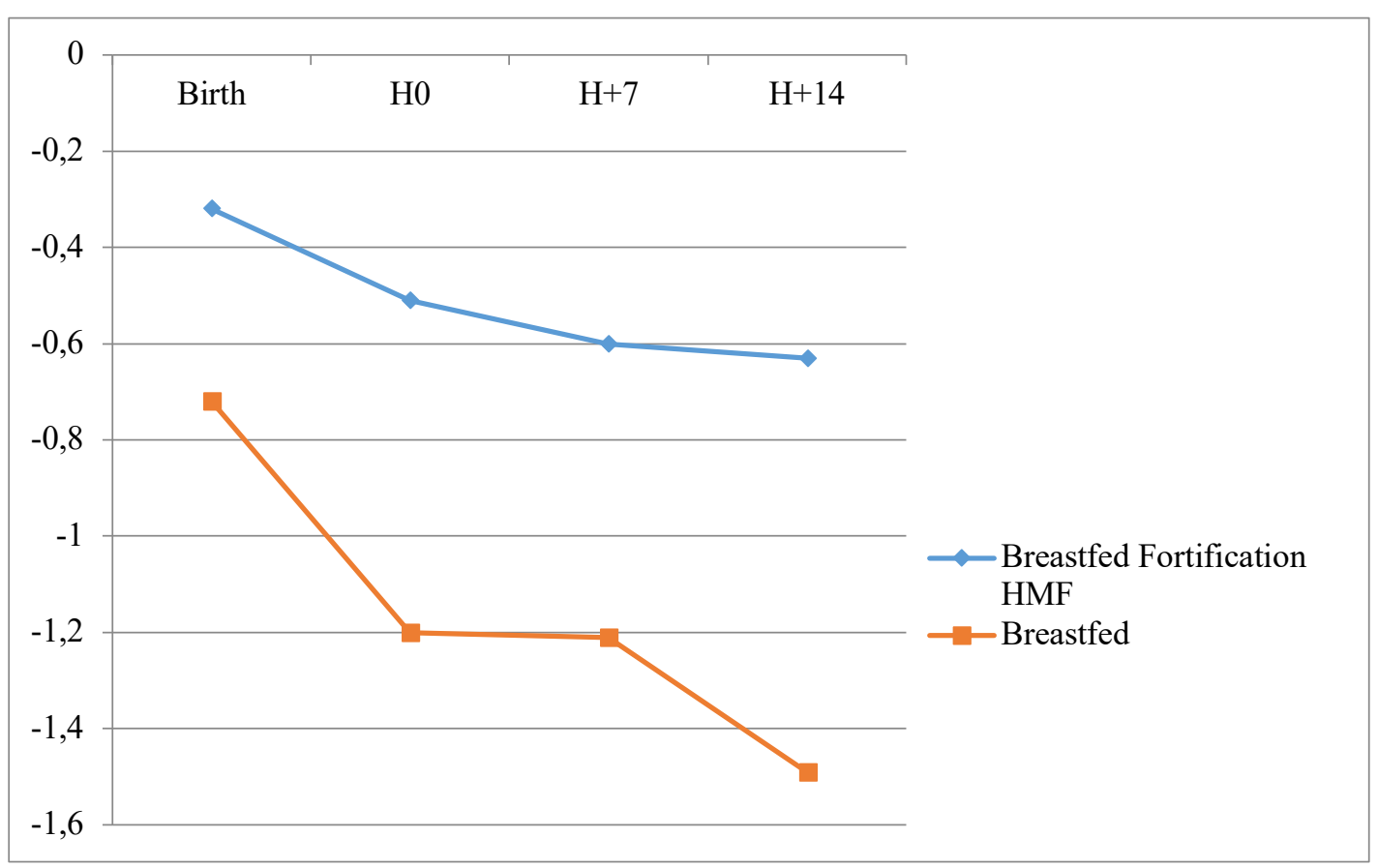

Figure 2. Comparison of mean age-for-age (z-score) scores between Breastfed and breast milk groups was fortified by HMF. Description: blue line is a group of Breastfed fortified HMF and red line is a breastmilk group. The $p$ value is significant when the value is $<0,05$. Independent $t$-test test sample.

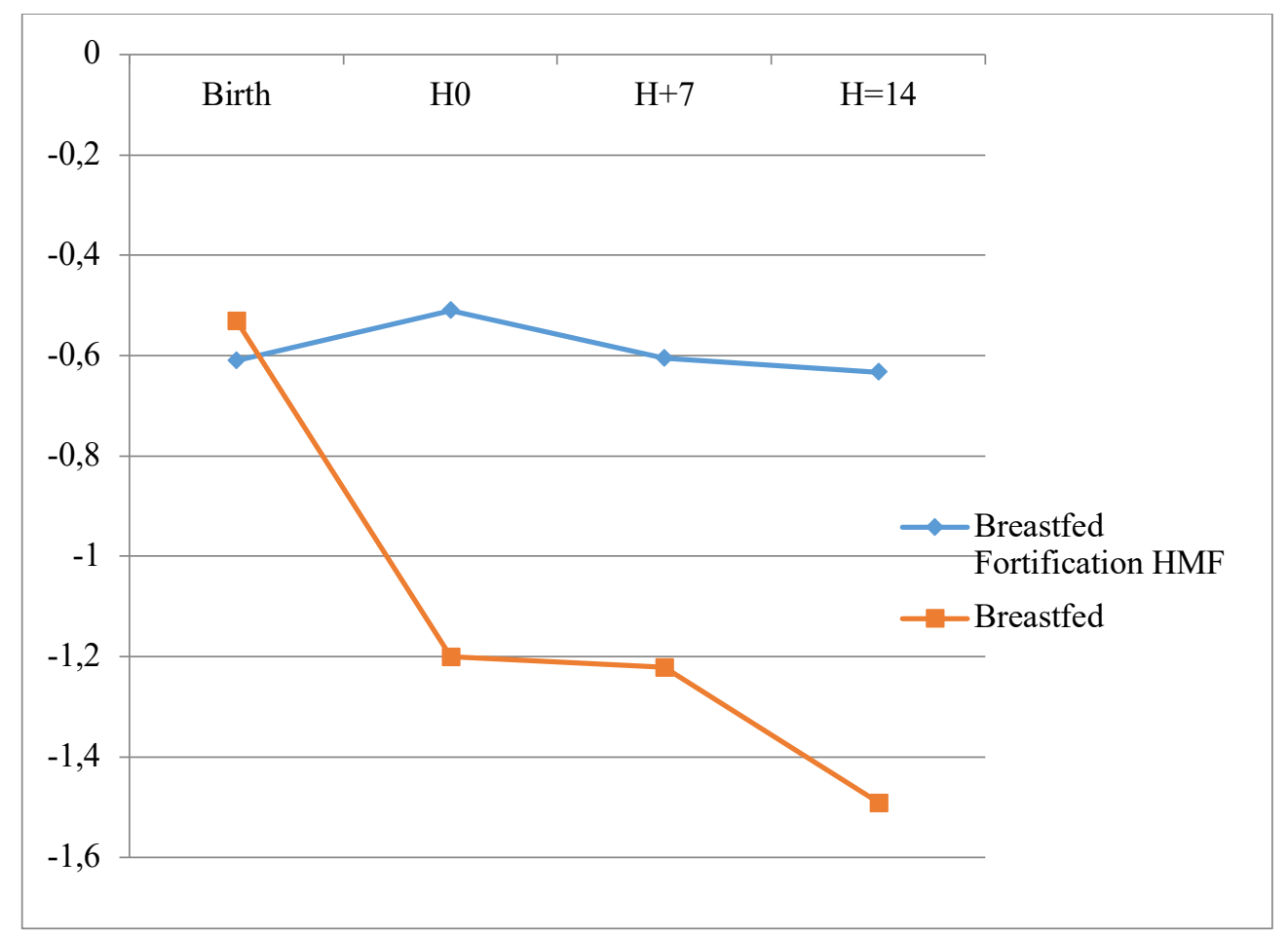

Figure 3. Comparison of mean z-score head circumference between breastmilk and breast milk group was fortified by HMF. Description: blue line is a group of breastmilk fortified HMF and red line is a breastmilk group. The $p$ value is significant when the value is $<0,05$. Mann-Whitney ${ }^{1}$ test and independent t-test sample ${ }^{2}$. 
The median birth weight of breastfed milk group HMF in this research was 1650 (10001950) gram, according to Mukhopadhyay et al., the average birth weight of $1202 \pm 202$ grams (Mukhopadhyay et al., 2007). The Cochrane Review also mentions the indication of breastfeeding fortification as a term infant with a mean birth weight of 900-1850 grams (Kuschel and Hardling, 2004). The mean of body length was born in breastmilk group $41,58 \pm 2,92 \mathrm{~cm}$ and breastfeeding group was fortified HMF 41,58 $\pm 3,04 \mathrm{~cm}$. Both groups had normal mean birth rates and no significant differences. Research by Arslanoglu showed prematurity infants has a mean length of body born 38,9 $2,2 \mathrm{~cm}$ (Arslanoglu et al., 2006). In this study, head circumference was born in the ASI group of 29 (25-32) cm and the breastfed group was fortified HMF $29(22-31) \mathrm{cm}$. Both groups had normal head circumference and no significant differences. In contrast to previous studies, the mean birth circumference of underweight infants who received breast milk fortification was $27.7 \pm 2.2 \mathrm{~cm}$ (Arslanoglu et al., 2006).

Both groups showed no significant differences in body weight, body length $(\mathrm{cm})$ and head circumference $(\mathrm{cm})$. Body weight in breastfed group 1590 (1070-1950) grams and breastfed groups fortified HMF 1620 (11601770) grams. The mean body length in the breastmilk group was $42.53 \pm 2,70 \mathrm{~cm}$ and the breastfed group was fortified HMF 43,09 $\pm 2,50$ $\mathrm{cm}$. The breastmilk group had a head circumference of $29(25-32) \mathrm{cm}$ and the breastmilk group fortified HMF 29 (22-31) cm (Table 4). In previous RCT studies showed the initial weight of the study $1189 \pm 209$ grams (Mukhopadhyay et al., 2007). The study by Morlacchi et al. also showed less-than-matured infants with an initial body weight of $1412 \pm 231$ gram (Morlacchi et al., 2016). The mean weightto-age (z-score) and length-for-age (z-score), body weight before breast milk fortification showed a decline compared to birth weight and length of birth. However, both groups showed no meaningful differences (Figure 1).
Prematurity Infants get breastfeeding fortified HMF at chronological age of $11.41 \pm$ 3.54 days. Both groups showed no significant difference (Table 4). Breastfeeding fortification begins at the age of chronologically 11 days (Adamkin, 2009) or at chronological age 4-15 days (Kuschel and Hardling, 2004). RCT study in 85 under-term infants stated that breastfeeding fortification was performed at the age of $11.8 \pm 5.7$ days (Mukhopadhyay et al., 2012). Other studies initiated breastfeeding fortification in underweight infants at chronological age of 13 (10-16) days (Miller et al., 2012).

Breastmilk fortification was given when the study subjects had enteral nutrition ability of $140.94 \pm 22.7 \mathrm{ml} / \mathrm{kg} /$ day. Both groups showed no significant difference to the mean enteral volume at baseline (Table 4). Previous studies have found that breastfeeding fortification begins when the prematurity infant had an enteral ability on $150 \mathrm{ml} / \mathrm{kg} /$ day (Arslanoglu et al. 2006, Adamkin, 2009), 45-170 ml / kg / day (Kuschel and Hardling, 2004). An RCT study of 85 underweight babies mentioned fortification when achieving enteral ability of $168 \pm 14.4 \mathrm{ml} / \mathrm{kgbb} /$ day (Mukhopadhyay et al., 2012). Miller et al. did fortification of breastfeeding when prematurity infant had an enteral ability of $120(94-140) \mathrm{ml} / \mathrm{kg} /$ day (Miller et al., 2012).

In this research, 4 underweight infants (gestational age 28-33 weeks and birth weight $750-1500$ grams) who received HMF of $24 \mathrm{kcal}$ / oz showed sepsis incidence with feeding intolerance more often than 2 infants less months (gestational age 31-33 week and birth weight 1400-1500 gram) that get HMF of 22 kcal / oz. Schutzman et al. mentions the fortification technique of ASK $22 \mathrm{kkal}$ / oz given to prematurity infants with birth weight 1000 1500 gram since chronological age 10 days for 6 days continued fortification of ASK $24 \mathrm{kkal} /$ oz. While in prematurity infants with birth weight 1500-2000 gram get fortification $22 \mathrm{kcal}$ / oz since chronological age 9 days for 4 days (Schutzman et al., 2012). Radmacher and Adamkin recommend giving fortification of 
breastmilk for 2-8 weeks with protein intake of $3.5-4.4 \mathrm{~g} / \mathrm{kg} /$ day and calories of $24 \mathrm{kcal} / \mathrm{oz}$ (Radmacher and Adamkin, 2016).

In this study, the growth rate of body weight showed significant differences between the two groups. The growth rate of breastfeeding fortification HMF group weight was found on 22 $(12,86-51,76) \mathrm{g} / \mathrm{kg} /$ day to be greater than breastfeeding group $14,28(-12,86-(+32,86)) \mathrm{g}$ $/ \mathrm{kg} /$ day (Table 6). Changes in weight (grams) and age-related weight (z-score) also showed significant differences (Table 5). Other studies with fortified breastfeeding techniques of 24 $\mathrm{kcal} / \mathrm{oz}$ had a lower body weight growth rate of $18.2 \pm 0.7 \mathrm{~g} \mathrm{/} \mathrm{kg} \mathrm{/} \mathrm{day} \mathrm{(Barrus} \mathrm{et} \mathrm{al.,} \mathrm{2012)} \mathrm{and}$ $15.1 \pm 4 \mathrm{~g} / \mathrm{kg} /$ day (Mukhopadhay et al., 2007). The differences in the rate of weight gain can be influenced by the characteristics of the study subjects (low birth weight, gestational age, history of steroid delivery before delivery, gender and APGAR score) and HMF composition (Kartal et al., 2016). In this study, only a small proportion of preterm infants had prematurely ruptured membranes and no significant difference was found (Table 3).

The researchers used the fortification technique of ASK $22 \mathrm{kkal} / \mathrm{oz}$ of 2 sachets of HMF $+100 \mathrm{ml}$ of breast milk. HMF product in this study contains protein $0.6 \mathrm{~g} / 100 \mathrm{ml}$ of milk, fat $0.18 \mathrm{~g} / 100 \mathrm{ml}$ of milk and carbohydrate 0.9 $\mathrm{g} / 100 \mathrm{ml}$ of breastmilk. The fortified milk fortification technique $24 \mathrm{kcal} / \mathrm{oz}$ in the Porcelli et al. study contained $1 \mathrm{~g} / 100 \mathrm{ml}$ of milk protein, $0.05 \mathrm{~g} / 100 \mathrm{ml}$ of breast milk and $2 \mathrm{~g} /$ $100 \mathrm{ml}$ of breast milk and the study showed $27 \%$ feeding intolerance, $30 \%$ respiratory distress and $36 \%$ cardiovascular disorders (Porcelli et al., 2000).

The caloric value used in the study was $144.47 \pm 10.03 \mathrm{kcal} / \mathrm{kg} /$ day (HMF fortified breastfeeding group) and $119.17 \pm 141.7 \mathrm{kcal} / \mathrm{kg}$ / day (breastfeeding group) (Table 8). Caloric mean of both study groups was in accordance with the recommendation of prematurity infants' caloric needs on $105-135 \mathrm{kcal} / \mathrm{kg} /$ day (Canadian pediatric society nutrition committee, 1995). Caloric mean showed significant differences (Table 8).
The mean of enteral volume in this study did not show significant difference (Table 7). The mean of enteral volume in breastmilk group was fortified HMF $175.04 \pm 13,91 \mathrm{ml} / \mathrm{kg} /$ day and breastfeeding group $178,42 \pm 17,85 \mathrm{ml} / \mathrm{kg} /$ day. The mean of breast milk protein content of prematurity infants with chronological age $15,3 \pm 1,5$ day is $2 \mathrm{~g} / 100 \mathrm{ml}$ of breastmilk (Porcelli et al., 2000). The HMF product used contained $0.6 \mathrm{~g} / 100 \mathrm{ml}$ of breastmilk in this study. Thus, the mean protein was $5.44 \pm 0.49 \mathrm{~g}$ $/ \mathrm{kg} /$ day (HMF fortified breastfeeding group) and $3.43 \pm 0.42$ (breastfeeding group). The breastfed group of fortified HMF had a higher mean protein and was significantly different for the breastmilk group (Table 9). Levels of protein intake in this study have been in accordance with the recommendation of protein needs for prematurity infants 3-3.6 g/kg/day (Canadian pediatric society nutrition committee, 1995). Systematic reviews indicate that administration of high-dose protein (3-4 $\mathrm{g} / \mathrm{kg} /$ day) may increase body weight by $23.6 \mathrm{~g} / \mathrm{kg} /$ day (Miller $e t$ al. 2008). Other studies have suggested that giving $2-4 \mathrm{~g} / \mathrm{kg} /$ day protein can increase BB, linear growth, nitrogen retention and albumin levels (Kuschel and Hardling, 2004). The HMF product in this study contains MCT of $9.6 \%$. Meta-analysis showed no significant difference between the number of doses of MCT on weight gain, body length (Klenoff-Blumberg and Genen, 2003).

Breastfed fortified HMF groups had a higher mean age-to-weight (z-score). The breastfed fortified HMF group had a positive effect on the mean age weight (z-score) (Figure 1). In this study, mean age weight (z-score) showed a decrease in both groups. The decrease in body length by age (z-score) is greater than the zscore (Figure 1 and 2). Previous research has shown that age-related z-score is greater than zscore (Ramel et al., 2012; Olsen et al., 2014). Zscore weight loss was lower in the group receiving high-dose calories and protein (5 grams FM $85+100 \mathrm{ml}$ of breast milk and 1-2.5 grams of Protifar $+100 \mathrm{ml}$ of breast milk). The administration of high-dose protein had a significant difference to age-z-score (Roggero et 
al., 2012). Larger weight growth rates (36 $\mathrm{g} / \mathrm{kg} /$ day and levels of $6.3 \mathrm{~g} / \mathrm{kg} /$ day) are expected to match the intrauterine growth rate (Olsen et al., 2010).

Table 5. Changes in anthropometric and immunoglobulin A values during the study

\begin{tabular}{|l|c|c|c|}
\hline \multicolumn{1}{|c|}{ Changes } & $\begin{array}{c}\text { Breastfed } \\
(\mathbf{n = 1 7 )}\end{array}$ & $\begin{array}{c}\text { Breastfed } \\
\text { Fortification HMF } \\
(\mathbf{n = 1 7 )}\end{array}$ & $\mathbf{p}$ \\
\hline Anthropometry & & & \\
\hline Weight (g) & $192,65 \pm 170,78$ & $355,88 \pm 162,30$ & $\mathbf{0 , 0 0 8}$ \\
\hline Weight to Age (z-score) & $-0,52 \pm 0,46$ & $-0,18 \pm 0,36$ & $\mathbf{0 , 0 2 2}^{\mathbf{2}}$ \\
\hline Length (cm) & $1(0-5)$ & $1,5(0-4)$ & $0,146^{1}$ \\
\hline Length to Age (z-score) & $-0,51(-1,01-(+1,28))$ & $-0,39(-0,86-(+0,80))$ & $0,185^{1}$ \\
\hline $\begin{array}{l}\text { Head Circumference } \\
\text { (cm) }\end{array}$ & $1(0-3,5)$ & $1,5(1-3)$ & $0,154^{1}$ \\
\hline $\begin{array}{l}\text { Head Circumference to } \\
\text { Age (z-score) }\end{array}$ & $-0,14 \pm 0,55$ & $0,18 \pm 0,43$ & $0,068^{2}$ \\
\hline Immunoglobulin A & & & \\
\hline \multicolumn{1}{|l|}{$\begin{array}{l}\text { IgA secretory fecal } \\
(\mu g / m l)\end{array}$} & $32,92(5,13-$ & $46,18(0,43-$ & $0,796^{1}$ \\
\hline
\end{tabular}

Description: The value of $\mathrm{p}$ is significant when the value $<0,05$. Mann-Whitney ${ }^{1}$ test and t-test independent sample ${ }^{2}$ test.

Table 6. Rate of short-term growth

\begin{tabular}{|l|c|c|c|}
\hline \multicolumn{1}{|c|}{ Characteristic } & Breastfed (n=17) & $\begin{array}{c}\text { Breastfed } \\
\text { Fortification HMF } \\
(\mathbf{n = 1 7 )}\end{array}$ & $\mathbf{p}$ \\
\hline Weight (g/kg/day) & $\begin{array}{c}14,28(-12,86- \\
(+32,86))\end{array}$ & $22(12,86-51,76)$ & $\mathbf{0 , 0 2 0}$ \\
\hline Length(cm/week) & $0,50(0-2,50)$ & $0,75(0-2)$ & 0,257 \\
\hline $\begin{array}{l}\text { Head Circumference } \\
\text { (cm/week) }\end{array}$ & $0,50(0-1,75)$ & $0,75(0,50-1,50)$ & 0,215 \\
\hline
\end{tabular}

Description: The value of $p$ is significant when the value $<0,05$ Mann-Whitney Test.

Table 7. The average of enteral volume

\begin{tabular}{|l|c|c|c|}
\hline \multicolumn{1}{|c|}{ Volume } & Breastfed & $\begin{array}{c}\text { Breastfed } \\
\text { Fortification HMF } \\
(\mathbf{n}=\mathbf{1 7})\end{array}$ & $\mathbf{p}$ \\
\hline Enteral Volume (ml/kg) & $\begin{array}{c}\mathbf{( n = 1 7 )} \\
3,43(232,29-\end{array}$ & $\begin{array}{c}304,29(219,43- \\
334,39)\end{array}$ & $0,809^{1}$ \\
\hline $\begin{array}{l}\text { Enteral Volume } \\
\text { (ml/kg/day) }\end{array}$ & $178,42 \pm 17,85$ & $175,04 \pm 13,91$ & $0,151^{2}$ \\
\hline
\end{tabular}

Description: The value of $\mathrm{p}$ is significant when the value $<0,05$. Mann-Whitney ${ }^{1}$ test and independent $t-$ test sample ${ }^{2}$. 
Table 8. Caloric average

\begin{tabular}{|c|c|c|c|}
\hline Caloric & $\begin{array}{c}\text { Breastfed } \\
(n=17) \\
\end{array}$ & $\begin{array}{c}\text { Breastfed } \\
\text { Fortification HMF } \\
(\mathrm{n}=17)\end{array}$ & $\mathbf{p}$ \\
\hline Caloric (kkal/day) & $190,72 \pm 27,69$ & $227,53 \pm 21,81$ & $<0,0001$ \\
\hline Caloric (kkal/kg/day) & $119,17 \pm 14,17$ & $144,47 \pm 10,03$ & $<0,0001$ \\
\hline
\end{tabular}

Description: The value of $\mathrm{p}$ is significant when the value $<0,05$. Test t-test independent sample.

Table 9. The mean protein

\begin{tabular}{|c|c|c|c|}
\hline Protein & $\begin{array}{l}\text { Breastfed } \\
(n=17)\end{array}$ & $\begin{array}{c}\text { Breastfed } \\
\text { Fortification HMF } \\
(n=17)\end{array}$ & $\mathbf{p}$ \\
\hline Protein (gram/day) & $5,82(4,65-6,77)$ & $9,26(6,78-10,17)$ & $<0,0001^{1}$ \\
\hline Protein (gram/kg/day) & $3,43 \pm 0,42$ & $5,44 \pm 0,49$ & $<0,0001^{2}$ \\
\hline
\end{tabular}

Description: The value of $\mathrm{p}$ is significant when the value $<0,05$. Mann-Whitney ${ }^{1}$ test and independent $\mathrm{t}$ test sample ${ }^{2}$.

The growth rate of body length showed no significant difference. The breastfed milk group HMF has a growth rate of body length of 0.75 $(0-2) \mathrm{cm} /$ week (Table 6). The growth rate of length breastfeeding fortified HMF group showed that varied results on recommendation of ideal infant growth less than $0.9 \mathrm{~cm} /$ week (Bertino et al., 2008). Breast fortification $24 \mathrm{kcal}$ / oz for 2 weeks showed growth rate of body length $0,9 \pm 0,1 \mathrm{~cm} /$ week and did not show significant difference. The protein content in this study was $1 \mathrm{~g} / 100 \mathrm{ml}$ of breast milk (Porcelli et al., 2000). Breastfed fortification $24 \mathrm{kcal} / \mathrm{oz}$ other shows the growth rate of body length is $0.86 \pm 0,2 \mathrm{~cm} /$ week while breastfeeding group $1.04 \pm 0,3 \mathrm{~cm}$. HMF is given in prematurity infants until it reaches 2000 grams (Mukhopadhyay et al., 2007). Research by Reis et al showed that a growth rate is $1.09 \pm 29 \mathrm{~cm} /$ week (Reis et al. 2000). HMF with high-dose protein has a growth rate of $1.15(1.10-1.19) \mathrm{cm}$ / week (Miller et al., 2012). Administration of adjustable fortification $(1,3 \pm 0,5 \mathrm{~cm} /$ week $)$ did not show significantly different body length growth rate against standard fortification (1,1,0,4 cm / week) (Arslanoglu et al., 2006). High doses of protein did not show any significant difference to the increase in body length (Miller et al., 2012; Roggero et al., 2012). This is caused by the level of milk protein is dynamic (Gidrewic et al., 2014). Thus, the calorie and protein levels given in this study, Miller et al and Roggero et al. were lower than those of Arslanoglu et al.

The breastfed fortified HMF group had a mean length of body-age (z-score) higher than the breastmilk group and showed a significant difference. The breastfeeding fortified HMF group was able to maintain a z-score average in the normal range (Figure 2). A z-score reduction in mean age was greater than the mean $\mathrm{z}$-score (Figure 1 and Figure 2). In line with previous studies, breastfeeding fortified HMF showed a decline in mean age-for-age (z-score) (Miller et al., 2012; Ramel et al., 2012; Olsen et al., 2014).

The HMF product in this study contained $58.4 \mathrm{mg}$ calcium and $33.6 \mathrm{mg}$ phosphorus per $100 \mathrm{ml}$ of breast milk. The use of HMF products with calcium $87 \mathrm{mg}$ and phosphorus $50 \mathrm{mg}$ to body weight 2000 gram showed growth rate of body length is $0.86 \pm 0.08 \mathrm{~cm}$. The rate of body length growth in the Gross et al study, have not met the recommended recommendation of 0.9 $\mathrm{cm} /$ week (Bertino et al., 2008). Although the mineral content in this study was lower but the growth rate of body length was faster than that of Gross et al. This is due to the composition of breastmilk and the characteristics of research subjects.

In this study, head circumference growth rate showed no significant difference $(p=0,215)$ 
(Table 6). The breastfed group of fortified HMF had a larger head circumference growth rate of 0.75 ( 0.50 to 1.50$) \mathrm{cm} /$ week than the breastmilk group of $0.50(0-1.75) \mathrm{cm} /$ week (Table 6). Fortification techniques of $24 \mathrm{kcal} / \mathrm{oz}$ milk and protein $0.9 \mathrm{~g} / 100 \mathrm{ml}$ of breast milk showed a change in head circumference of $1.04 \quad 0.23 \mathrm{~cm}$ / week $(\mathrm{p}=0.743)$ (Reis et al., 2000). A study by Porcelli et al. gave HMF to less than 2 months of gestational weight to a body weight of 2000 grams but this did not show any significant difference (Porcelli et al. 2000). High doses of protein did not show significantly different head circumference growth rates $(p=0.330)$. The rate of head circumference growth in less-than-term infants who received high-dose protein was 0.94 $(0.9-0.98) \mathrm{cm} /$ week (Miller et al., 2012). In contrast to the milk fortification technique of 24 $\mathrm{kcal} / \mathrm{oz}$ with protein of $0.9 \mathrm{~g} / 100 \mathrm{ml}$ of breast milk and $0.8 \mathrm{~g} / 100 \mathrm{ml}$ showed a larger head circumference growth rate of $1 \pm 0.1 \mathrm{~cm} /$ week and $0.8 \pm, 1 \mathrm{~cm} /$ week (Porcelli et al., 2000). The mean age-zero head circumference (zscore) of breastmilk group was fortified with HMF higher than in breastmilk group. Breastfeeding fortification maintains an average $z$-score head circumference in the normal range (Figure 4). Higher calorie and protein intake showed significant differences in mean ageadded z-score (Miller et al., 2012).

\section{Conclusions}

Short-term growth rate based on body weight showed significant differences while the parameters of body length and head circumference did not show significant differences between prematurity infants of breastfeeding and breastfeeding were fortified with HMF, and the secretory IgA fecal content showed no significant difference between breastfed infants who were breastfed and breast milk fortified with HMF.

\section{References}

Adamkin DH, (2009). Human milk. In Adamkin DH (eds), Nutritional strategies for the very low birthweight infants. New York: Cambridge University Press, pp 111-18.

American Academy of Nutrition Committee on Nutrition. (1977). Nutritional needs of low birth weight infants. Pediatrics, 60(4): 51930.

Araújo, E. D., Gonçalves, A. K., Cornetta, M. D. C., Cunha, H., Cardoso, M. L., Morais, S. S., \& Giraldo, P. C. (2005). Evaluation of the secretory immunoglobulin A levels in the colostrum and milk of mothers of term and pre-trerm newborns. Brazilian Journal of Infectious Diseases, 9(5), 357-362.

Arslanoglu, S., Moro, G. E., \& Ziegler, E. E. (2006). Adjustable fortification of human milk fed to preterm infants: does it make a difference?. Journal of Perinatology, 26(10), 614.

Barrus, D. M., Romano-Keeler, J., Carr, C., Segebarth, K., Claxton, B., Walsh, W. F., \& Flakoll, P. J. (2012). Impact of enteral protein supplementation in premature infants. Res Rep Neonatol, 2, 25-31.

Bertino, E., Boni, L., Rossi, C., Coscia, A., Giuliani, F., Spada, E., et al. (2008). Evaluation of postnatal growth in very low birth weight infants: a neonatologist's dilemma. Pediatric endocrinology reviews: PER, 6(1), 9-13.

Canadian Medical Association. (1995). Nutrient needs and feeding of premature infants. Nutrition Committee, Canadian Paediatric Society. Canadian Medical Association Journal, 152(11), 1765-1785.

Colaizy, T. T., Carlson, S., Saftlas, A. F., \& Morriss, F. H. (2012). Growth in VLBW infants fed predominantly fortified maternal and donor human milk diets: a retrospective cohort study. BMC pediatrics, 12(1), 124.

Cooke, R. W. I., \& Foulder-Hughes, L. (2003). Growth impairment in the very preterm and cognitive and motor performance at 7 years. Archives of Disease in Childhood, 88(6), 482-487.

Fanaroff, A. A., Stoll, B. J., Wright, L. L., Carlo, W. A., Ehrenkranz, R. A., Stark, A. R., et al. (2007). Trends in neonatal morbidity and mortality for very low birthweight infants. 
American journal of obstetrics and gynecology, 196(2), 147-e1.

Gidrewicz, D. A., \& Fenton, T. R. (2014). A systematic review and meta-analysis of the nutrient content of preterm and term breast milk. BMC pediatrics, 14(1), 216.

Gross, S. J. (1987). Bone mineralization in preterm infants fed human milk with and without mineral supplementation. The Journal of Pediatrics, 111(3), 450-458.

Kartal, Ö., Aydınöz, S., Kartal, A. T., Kelestemur, T., Caglayan, A. B., Beker, M. C., et al. (2016). Time dependent impact of perinatal hypoxia on growth hormone, insulin-like growth factor 1 and insulin-like growth factor binding protein-3. Metabolic brain disease, 31(4), 827-835.

Kementerian Kesehatan Republik Indonesia. (2013). Peraturan Menteri Kesehatan Republik Indonesia Nomor 39 Tahun 2013 tentang Susu Formula Bayi dan Produk Bayi Lainnya. Jakarta, DKI: Penulis. Available at:

http://farmalkes.kemkes.go.id/?wpdmact=p rocess\&did $=$ OTEuaG90bGluaw $==$.

Accessed on February 23th 2017

Klenoff-Brumberg H. L. \& Genen L. H. 2003. High versus low medium chain triglyceride content of formula for promoting short term growth of preterm infants. Cochrane Database Syst Rev, (1): CD002777.

Kuschel, C. A., \& Harding, J. E. (2000). Multicomponent fortified human milk for promoting growth in preterm infants. The Cochrane database of systematic reviews, (2), CD000343-CD000343.

Leppänen, M., Lapinleimu, H., Lind, A., Matomäki, J., Lehtonen, L., Haataja, L., \& Rautava, P. (2014). Antenatal and postnatal growth and 5-year cognitive outcome in very preterm infants. Pediatrics, 133(1), 6370.

Miller, J., Makrides, M., \& Collins, C. T. (2008). High versus standard protein content of human milk fortifier for promoting growth and neurological development in preterm infants. Cochrane Database of Systematic Reviews, 10: CD007090.
Morlacchi, L., Mallardi, D., Giannì, M. L., Roggero, P., Amato, O., Piemontese, P., et al. (2016). Is targeted fortification of human breast milk an optimal nutrition strategy for preterm infants? An interventional study. Journal of translational medicine, 14(1), 195.

Mukhopadhyay, K., Narang, A., \& Mahajan, R. (2007). Effect of human milk fortification in appropriate for gestation and small for gestation preterm babies: a randomized controlled trial. Indian Pediatrics, 44(4), 286.

Olsen, I. E., Groveman, S. A., Lawson, M. L., Clark, R. H., \& Zemel, B. S. (2010). New intrauterine growth curves based on United States data. Pediatrics, peds-2009.

Olsen, I. E., Harris, C. L., Lawson, M. L., \& Berseth, C. L. (2014). Higher protein intake improves length, not weight, $\mathrm{z}$ scores in preterm infants. Journal of pediatric gastroenterology and nutrition, 58(4), 409416.

Peraturan Pemerintah Republik Indonesia. (2012). Peraturan Pmerintah RI Nomor 33 Tahun 2012 tentang Pemberian Air Susu Ibu Eksklusif. Jakarta, DKI: Penulis. Available at:

http://gizi.depkes.go.id/download/PP\%20no .\%2033\%20tahun $\% 202012 \% 20$ tentang\%20 pemberian\%20ASI\%20eksklusif.pdf.

Accessed on January 21th 2017

Porcelli, P., Schanler, R., Greer, F., Chan, G., Gross, S., Mehta, N., et al. (2000). Growth in human milk-fed very low birth weight infants receiving a new human milk fortifier. Annals of Nutrition and Metabolism, 44(1), 2-10.

Radmacher P. G. \& Adamkin D. H. (2016). Fortification of human milk for preterm infants. Semin Fetal Neonatal Med, 165(16): 1-6.

Ramel, S. E., Demerath, E. W., Gray, H. L., Younge, N., Boys, C., \& Georgieff, M. K. (2012). The relationship of poor linear growth velocity with neonatal illness and two-year neurodevelopment in preterm infants. Neonatology, 102(1), 19-24. 
Reali, A., Greco, F., Fanaro, S., Atzei, A., Puddu, M., Moi, M., \& Fanos, V. (2010). Fortification of maternal milk for very low birth weight (VLBW) pre-term neonates. Early human development, 86(1), 33-36.

Reis, B. B., Hall, R. T., Schanler, R. J., Berseth, C. L., Chan, G., Ernst, J. A., et al.. (2000). Enhanced growth of preterm infants fed a new powdered human milk fortifier: a randomized, controlled trial. Pediatrics, 106(3), 581-588.

Roggero, P., Giannì, M. L., Orsi, A., Amato, O., Piemontese, P., Liotto, N., et al. (2012). Implementation of nutritional strategies decreases postnatal growth restriction in preterm infants. PLoS One, 7(12), e51166.

Schutzman, D. L, Porat, R., Salvador, A. \& Janeczko M., (2012). Parenteral and Enteral Nutrition of the Low Birth Weight Infant. In: Schutzman DL (eds). Handbook of growth and growth monitoring in Health and Disease. Philadelphia: Springer Science Business Media, pp 2507-21

\section{Acknowledgment}

We would like to thank our teacher Fatimah Indarso for supporting this research. We also appreciate the helped of Kinanti Ayu Ratnasari for editing this manuscript. 